\title{
THE SOCIOECONOMIC IMPACTS OF AGROPOLITAN PROJECT IN THE RURAL AREAS OF THE EAST COAST REGION OF MALAYSIA
}

\author{
Abdul Rahman Abdul Latip ${ }^{1 *}$, Osman Md Yusoff ${ }^{2}$ and Mohamad Shaharudin \\ Samsurijan $^{2}$
}

${ }^{1}$ Faculty of Business, Economic and Social Development, Universiti Malaysia Terengganu, Terengganu, MALAYSIA

${ }^{2}$ School of Social Sciences, Universiti Sains Malaysia, Pulau Pinang, MALAYSIA *Corresponding author: rahmanlatip89@yahoo.com

Published online: 30 April 2020

To cite this article: Abdul Rahman Abdul Latip, Osman Md Yusoff and Mohamad Shaharudin Samsurijan. 2020. The socioeconomic impacts of agropolitan project in the rural areas of the east coast region of Malaysia. Kajian Malaysia 38(1): 47-65. https://doi.org/10.21315/km2020.38.1.3

To link to this article: https://doi.org/10.21315/km2020.38.1.3

\begin{abstract}
In 2007, Kelantan and Terengganu were among the states with the highest poverty rates in Malaysia. The East Coast Economic Region (ECER) Master Plan, approved by the Malaysian Government in 2008, was formulated as a basis to guide the development of ECER until 2020. It identifies projects and programmes to reduce regional socioeconomic disparities, eradicate poverty and improve income and wealth distribution in a sustainable manner. The Agropolitan Project is an integrated socioeconomic scheme initiated by ECER with the ultimate aim of eradicating poverty among the most impoverished communities within the region. This study aims to analyse the socioeconomic impacts of the Agropolitan Project that has been implemented in rural areas of Kelantan, Terengganu and Pahang. The study uses the quantitative method by administering a set of questionnaires to 97 respondents from the Agropolitan Project across the ECER states. It also uses the qualitative approach (in-depth interviews with ten key informants and two sessions of a focus group discussion) including direct observation, as well as deskbased research. This study found positive changes in some of the participant's lives, with job opportunities and improvements to their standard of living. Nonetheless, more effort is needed to ensure that the project achieves its vital objectives.
\end{abstract}

Keywords: regional development, rural poverty, socioeconomic impacts, East Coast Economic Region (ECER) 


\section{INTRODUCTION}

Over the last 40 years, the aims of the regional development policies and strategies have been to reduce regional disparities and underdevelopment among the various Malaysian regions. Most of the resources and infrastructure over this period were concentrated along the west coast of Malaysia, whilst conversely, recorded poverty and unemployment on the east coast was much higher. According to the Department of Statistics Malaysia, the poverty rate in the rural areas of Malaysia in 2007 was $7.1 \%$. The state of Sabah has the highest poverty rate at $16.4 \%$, followed by Kelantan (7.2\%), Perlis (7.0\%), and Terengganu (6.5\%) (Department of Statistics Malaysia 2008).

The level of development in Malaysia can be divided into two categories, less developed states and more developed states. According to the 10 indicators of composite development index used in the study, Kelantan, Terengganu and Pahang categorised under the less developed states (Mohamed Aslam and Asan Ali 2003). In the Ninth Malaysia Plan, the government was still concerned about the regional development imbalances and poverty issue in the less developed states, particularly in rural areas. The third phase of the plan gave attention to address the remaining persistent socioeconomic inequalities both constructively and productively. The allocation for rural development and comprehensive development of the worse areas has been increased to reduce disparities between rural and urban conurbations as well as between less developed and more developed regions (Economic Planning Unit 2006, 35). Eradication of the most poverty-stricken and overall poverty reduction will be the key priorities (Ibrahim 2012).

In line with the government's aspirations, the East Coast Economic Region (ECER) has been established based on the east coast of the Peninsular Malaysia which covers Kelantan, Terengganu, Pahang and the district of Mersing in Johor. It is an economic development region that spans about 12 years, beginning in 2007 and projected to end in 2020. There are another four economic development regions alongside ECER, namely Iskandar Development Region (IDR), the Northern Corridor Economic Region (NCER), the Sarawak Corridor of Renewable Energy (SCORE) and the Sabah Development Corridor (SDC). ECER mission is to eradicate the hardcore poverty among the states in the region, particularly in the rural areas. The various development programmes and projects aimed to increase household incomes, providing new jobs and entrepreneurial opportunities for the local populace. In realising the mission, ECER Master Plan formulated in 2008 as a basis to guide the development of the region from 2008 until 2020. Key initiatives identified and many programmes and projects planned for implementation within the 12 years. The high impacts and catalyst projects expected to spur the ECER development and reduce the issue of regional disparities between east coast and west coast of Peninsular Malaysia. 
In addition to the regional development programmes, several other programmes are being implemented and aimed at upskilling workers to ensure they are not left out of the social-economic development. The Agropolitan Project is an integrated socioeconomic project introduced by East Coast Economic Region Development Council (ECERDC). An industry-specific plan for the Agropolitan Project is a poverty eradication initiative using the agriculture sector as its platform. Participants, predominantly those in abject poverty are resettled and employed in the farming and livestock industry. The participants were chosen among the heads of households categorised as hardcore poor and the priority given to those registered under the e-Kasih system. An integrated approach has been adopted, with participants and their families moving into custom-built housing areas conducive to personal development and meaningful participation in the regional economy. Housewives are encouraged to work in secondary economic activities while school-age children of the participants are given opportunities to attend motivational classes and tuition classes to improve their academic grades. ECERDC cooperates with other government agencies, private sector, universities and NGOs to create a progressive and sustainable community that will play a significant role in ECER's economy. The participants are provided with training before they begin working in this agricultural project. Through these activities, the families are capable of generating a steady income ranging from RM1,000 to RM2,000 per month. This figure is projected to grow to RM5,000 per month by 2020 (ECERDC 2009).

The successful implementation of development programmes depends on the impact it brings to the local community. Blomquist (2003) stated that the single most critical policy question pertaining to a public programme is whether it is cost-effective. The programme or project must truly help those who participate in it. In order to answer this question, a special standard of evaluation known as programme impact evaluation is needed. An impact evaluation can provide detailed information to the government such as whether a project really benefits participants, it evaluates if the project is cost-effective and gives a greater insight into why a project may not deliver the outcomes as intended. Collectively, it provides the best evidence on the most effective programme or project that is likely to help local communities achieve its social goals.

During the administration of the fifth Prime Minister, Tun Abdullah Ahmad Badawi (2003-2009), one of the main focuses is on the outcome and impact rather than input or output of the project. Every government agency must ensure that the programme or project will achieve the desired outcomes and give maximum benefits to the target groups. A programme is considered a failure if it cannot deliver the desired outcomes (Khalid 2007). It has been continued by the sixth Prime Minister, Dato' Seri Najib Tun Abdul Razak, subsequently, there should an overall assessment of the long-term effects (positive or negative) to 
ascertain the eventual outcomes of any programme or project. Currently, there is a "missing point" in the project cycle of planning, implementation and evaluation as no evaluation of any singles projects and programmes were conducted since the closing of Socio-economic Research Unit (Osman et al. 2016).

Recently, the new regionalist theories emphasised the significance of socioeconomic impacts of development programmes. It has been the main indicator to not only look at the physical development but the effects it brings to the people in the community especially in remote or rural areas where the process of development longer compared to the urban area (Nik Maheran et al. 2011). In achieving sustainable regional development, economic growth must continuously be supported by the improvement in human development. Conversely, a slow in human development can ruin the fast-economic growth of a region (World Bank 2000).

In the previous study, Yusof et al. (2014) discussed the quality of life amongst participants of Agropolitan Project in Kelantan and Pahang and the discussion was limited to the issue of income, satisfaction and individual perception on the quality of life upon joining this programme. Hence, this article attempts to explore (1) the changes of income and occupation of the participants after joining this project, (2) the socioeconomic impacts of the project in improving the standard of living, and (3) the overall impacts of this project on participant's lives.

\section{Agropolitan Projects in East Coast Region of Malaysia}

In Malaysia, the government has introduced many agriculture projects that aim to increase the participant's income, provide job opportunities, improve the standard of living and reduce the poverty issue, particularly in rural areas. The projects such as Agropolitan Project, Zone Industry Aquaculture and Sustainable Food Production Park are among the projects that give many benefits to poor people.

Agropolitan Project under ECER is an integrated rural development project that aimed to eradicate hardcore poverty among the rural communities in the east coast region of Peninsular Malaysia. The method of implementation of the Agropolitan Project is divided into two; mainly relocation method and in situ development method. It involves the integration of three sectors which include agriculture, agro-based industries and rural industries. A total of three Agropolitan Projects have been developed over seven years, from 2009 to 2016, with one each in Pahang, Kelantan and Terengganu, where participants are resettled and work in plantation agriculture and the livestock industry.

As in Pahang, this project implemented in Pekan. There are three locations involved; Runchang, Batu 8 in Lepar and Tanjung Batu in Nenasi, which involved a total of 455 participants. Federal Land Development Authority (FELDA) has 
appointed as the implementing agency of the Pekan Agropolitan based on their successful experience in resettling landless farmers. This project began in 2009 with a pilot project has been implemented in Runchang for Orang Asli participants. They were employed to raise 3,000 heads of Dorper sheep in 35 animal production units. They can earn an average of RM850 a month by working at least five hours a day.

Meanwhile, the site in Batu 8 Lepar became operational in 2011 with 100 participants who also engaged in Dorper sheep rearing. Compared to Runchang, the participants of the Agropolitan Project in Batu 8 Lepar can earn an average monthly income of RM1,100. Besides, they established a cooperative under the name of Koperasi Agropolitan Lepar Berhad in April 2012. The main economic activity of this cooperative is poultry farming and they employ their family members to manage a total of 50,000 birds. It is the secondary activity of the Agropolitan Project in Batu 8 Lepar. As the members of the cooperative, they can expect to earn an additional income from the profits return of this project (ECERDC 2013).

In Kelantan, the Agropolitan Project implemented in Gua Musang. This South Kelantan Agropolitan commenced in 2009 and has been designed to assist 625 poor families. The primary activity is replanting and rehabilitation work on a 1,490-hectare oil palm plantation. For this purpose, ECERDC entered into a collaborative arrangement with Lembaga Kemajuan Kelantan Selatan (KESEDAR). Management of this project such as management of the primary and secondary income generating activities and financial management of the participants is under their responsibility. As an appointed agency for this project, they have to take care of the participants and their families. The pilot project completed in February 2009, with nine families moving into newly built homes. The participants are now working in an oil palm plantation that can earn an average monthly income of RM1,000. In September 2012, there were 204 participants in this Agropolitan Project, following the resettlement of the second batch of 195 participants. During the year, construction of 315 new homes was completed, supported with well-equipped public amenities and modern infrastructure. To increase their income, ECERDC has collaborated with the Malaysian Cocoa Board to introduce cocoa cultivation to the participants. It just uses the backyards of their homes and technical assistance provided. Their salary has been banked directly to their bank to improve the participant's financial management (ECERDC 2013).

The Besut-Setiu Agropolitan (Terengganu) located at Panchur Bederu, Mukim Chalok, Setiu. Again, FELDA has been appointed as the implementing agency for this Agropolitan Project. Construction works began in 2011 and completed in 2013. Under Phase 1, 100 participants were moving into new houses, supported by public amenities such as multipurpose hall, shops, kindergarten and 
mosque. The primary economic activity is Dorper sheep rearing. Apart from that, chicken rearing and livestock activities became their secondary income. This Phase 1 project also includes construction of 52 animal production units of sheep rearing and 104 hectares of Napier grass to feed a total of 4,680 sheep.

\section{LITERATURE REVIEW}

There are many scholars discussed the impacts of agriculture project in improving the socioeconomic status among poor people in rural areas. According to Rosegrant and Hazell (2001), economic growth that gives attention to agriculture has increased the incomes of poor families' farmers and landless labourers. Automatically, it is particularly effective in reducing the poverty issue. Evidence shows investment in agriculture project is more effective compared to nonagricultural sectors in reducing poverty among poorest people. It is also up to 3.2 times better at reducing poverty for countries that earning low-income and resources, including those countries in sub-Saharan Africa. However, not all investment in agriculture leads to poverty reduction as the agriculture sector itself is a broad sector.

In a study by Christiaensen, Demery and Kuhl (2011), the adoption of the Millennium Development Goals among the United Nations member states added a new dimension on the development focus. It has shifted the focus in development from only fostering economic growth to encouraging poverty reduction. It does not only depend on the rate of overall economic growth, but also on how the poor people could participate in that growth. The agriculture sector is playing a significant role in the development process as the majority of poor people in the developing world depend on agriculture for survival. The finding indicates that agriculture sector is significantly more effective in reducing poverty among the poorest of the poor.

Another study implies the significant and strong linkages between agricultural production and poverty in many circumstances. The empirical finding shows plausible impacts of agriculture project in reducing poverty including the creation of jobs, higher incomes for farmers, linkages from farming to the rest of the rural economy and reduced prices of food (Irz et al. 2001). In the previous literature discussed, a pro-rural development strategy in Bangladesh involving agriculture project managed to establish superiority in rural growth over urban growth for poverty alleviation. Moreover, a study on analysing poverty in Indonesia concludes that the effort to reduce poverty mainly contributed by growth within the agriculture sector.

Mellor (2001, quoted in Thirtle, Lin and Piesse 2003) argues that agricultural productivity growth effectively reduces poverty among poor farmers 
in rural areas. It generates income and increasing the demand for these goods and services. Indirectly, the increasing of agriculture productivity result in lower food prices and reduces urban poverty as there is a decline of migration to the urban areas. This positive impact leads to empowering the poor farmers by increasing their access to decision-making processes, increasing their capacity for collective action and reducing their vulnerability to shocks, through asset accumulation (Hazell and Haddad 2001, quoted in Thirtle, Lin and Piesse 2003). The finding of their study establishes a substantial impact between agricultural productivity growth and poverty reduction in the two poorest continents in Africa and Asia, as well as it is a profitable investment.

Mabaso (2014) in his study determine the impact of agricultural development projects on poverty alleviation at Amajuba district municipality, South Africa. The study is comparing the farmers that are joining the agriculture project and those that are working individually in alleviating poverty. The result shows that project participants are more productive as they have access to funding, training, market and extension service. Automatically, it helps to reduce poverty among the family of participants. Their standard of living is improving, and they can live a better life. Through the project, it will be much easier for them to receive government assistance and unite as a group. The individual that working alone in farming activities cannot afford to improve their standard of living and end up, they maintain in living a poor life. They do not have the skills and technology needed to improve their farming activities.

A study by Yusof et al. (2014) discussed the quality of life amongst Agropolitan participant project in Kelantan and Pahang. The result indicates the positive income progress every month before and after joining the Agropolitan project. The participants have a fixed job, fixed sources of income and better income. The participant express that they have a more assured life and a better lifestyle. Also, this project enhances work opportunities and reduces the poverty problem in Kelantan and Pahang. Their family also can live in a conducive environment and harmony residential area.

Besides, productivity gains from agriculture sector generally effective in reducing poverty globally (Ivanic and Martin 2018). In the study involving poor countries such as India, China, Bangladesh, Sri Lanka and Indonesia, the key finding shows the agriculture sector also proven effective in contributing to the increasing gross domestic product, on par with the industry or services sectors. A study by Darko et al. (2018) found the agriculture sector has brought positive impact on the welfare of the household in the rural agricultural areas in Malawi. The result indicated the increasing productivity of agriculture activities has a statistically significant positive impact in improving the availability of food and household income among the rural farmers. 


\section{METHODOLOGY}

The study has used both primary and secondary data to achieve the objectives. For the primary data, the integrative approach used, which utilised both quantitative and qualitative methods. In a quantitative method, a field survey using questionnaires issued to 97 participants from Agropolitan Project across the ECER states. A semistructured questionnaire was administered to the participants by proportionate random selection. The majority of the respondents are from the Agropolitan Project in Kelantan (44\%) and Pahang (44\%). The remaining $12 \%$ of respondents are from the Agropolitan Project in Terengganu. About $81 \%$ of the respondents are male and the rest are female. The participant's range of age is between 24 and 62 years old. Most of the respondents (41\%) obtained Sijil Pelajaran Malaysia (SPM) as their highest education level. The primary activity for Pekan Agropolitan and Besut Setiu Agropolitan participants is Dorper sheep rearing, while in South Kelantan Agropolitan, the primary activity is working in the palm plantation.

The first objective of this study measured by the occupation changes and income progress upon joining the Agropolitan Project. In the second objective, the socioeconomic impacts measured by the participant's perception of how the project affects their life in terms of economic, social and environment. The questionnaire designed on a positive scaling rate, in which 1 is the lowest rate and the highest is 5. In measuring the third objective, the rating scale used to gain their satisfaction expression on the overall impact of the project in transforming their life, in which 1 is the lowest and the highest is 10 . Then, few open-ended questions used to gain their view pertaining to their experience upon joining the project, any problems or issues occurred, and their opinion about the project operator. Statistical Package for Social Science (SPSS) software has been used in this study to analyse the data. The descriptive analysis and Crosstab analysis used to answer the objectives.

The study also uses a qualitative approach which includes in-depth interviews with 10 key informants and two sessions of focus group discussion (FGD) including direct observation. The informants comprised of three informants from the implementation level and the remaining seven informants are selected from the respondents involved in the questionnaire survey, in which three informants from Pahang state, and each two from Kelantan and Terengganu state. The FGD conducted with the project participants from Kelantan and Terengganu state. The in-depth interviews and FGDs conducted in the participant's language. All the conversation recorded upon consent from the interviewees and participants of FGD. Later, the interviews and discussions translated and transcribed. Each interview session took between 40 minutes to 1.5 hours. For the FGD, each session took about 1-2 hours. Content analysis used to systematically evaluate the interview transcriptions. NVivo software used to analyse the qualitative data. A pilot study conducted with a total of 30 survey questionnaires distributed to test 
the reliability of the questions. Ethical approval sought before the actual survey conducted. Apart from that, the secondary data was collected from the reliable and dependable sources such as official websites, reports, statistics, journals and articles.

\section{FINDINGS AND DISCUSSION}

\section{Changes of Occupation and Income of the Participants}

\section{Occupation}

Table 1 shows the occupation of respondents before and after participating in the Agropolitan Project. Most of the respondents (85\%) were self-employed before joining this project while $10 \%$ of the respondents were working in the private sector. On the other hand, $4 \%$ of them were jobless as they became full-time housewives. There was $1 \%$ of the respondents working in the government sector before joining this Agropolitan Project. Respondents who were self-employed earned less as they were unable to secure regular work. Through the study, most of the respondents indicate that they were not very academic, which is the main reason they were unable to increase their life chances. The majority of them are farmers, fishermen, contract labour or rubber tappers. There is no need for qualifications and extensive expertise to work in these sectors. Their income is dependent on the weather and therefore quite seasonal. As for the respondents involved in private and the government sector, they chose to join this Agropolitan Project because it provided them with a stable income, together with a new, fully-furnished house and public facilities such as kindergarten, multipurpose hall and surau. It can be seen that all respondents now have a stable full-time job in a conducive neighbourhood environment as participants of the Agropolitan Project. According to one of the participants in FGD at South Kelantan Agropolitan:

Before joining this project, I used to work as a rubber tapper. Consequently, my income wasn't stable. If it rained, it meant I couldn't work, and on that basis, it was quite hard to earnt RM600-RM700 per month. Now, my situation is much better, I have a stable job and a steady income to take care of my wife and children. (Respondent no. 9, Kelantan) 
Abdul Rahman Abdul Latip et al.

Table 1: Occupation of the participant before joining Agropolitan Project

\begin{tabular}{lcc}
\hline Occupation & Number & Percent \\
\hline Government & 1 & 1 \\
Private & 10 & 10 \\
Self-employed & 82 & 85 \\
Housewife & 4 & 4 \\
\hline Total & 97 & 100 \\
\hline
\end{tabular}

They do not have to worry about getting a stable job anymore as now, they have a full-time job in this project. They just need to work hard and show a good attitude as the house will be theirs in seven to ten years. This Agropolitan Project is quite special. Back in 2008, ECER aimed to eradicate the poverty in rural areas within this region. The participants have nothing before they joint this project. ECER brought them to a newly opened residential area. The scheme is like FELDA, even better than FELDA because this project got supports and assistance fully from the government. They do not need to pay back as what experienced in FELDA. A total development has been implemented specifically for this project, whereby, they got a permanent job with a stable income, a fully-furnished house, completed infrastructure and public amenities, kindergarden, mosque and shop lots provided for their usage. ECER help their children's transportation to go to school and they can involve in empower academic programme.

\section{Income}

Table 2 and Figure 1 reveal the monthly income of respondents before and after participating in the Agropolitan Project. The majority of the respondents (65\%) earned a monthly income of RM301-RM600 before joining this project, while 17\% of them earned RM300 per month or below. After joining the Agropolitan Project, none of the participants earned less than RM600 per month. The respondents with an income between RM601 and RM900 per month increased by $8 \%$. As expected, respondents with an income of RM901 and RM1,200 monthly increased by 57\%, and the top earners on a monthly income of RM1,201-RM1,500 increased their wages by $5 \%$. Table 2 shows none of the participant earning RM1,501-RM1,800 monthly, and after joining the project, this was increased by about $13 \%$. 
Table 2: Income progress

\begin{tabular}{lcclcc}
\hline \multicolumn{7}{c}{ Income $(\mathrm{RM})$} \\
\hline Before & Number & Percent & After & Number & Percent \\
\hline 300 and below & 16 & 17 & 300 and below & 0 & 0 \\
$301-600$ & 63 & 65 & $301-600$ & 0 & 0 \\
$601-900$ & 9 & 9 & $601-900$ & 16 & 17 \\
$901-1,200$ & 4 & 4 & $901-1,200$ & 59 & 61 \\
$1,201-1,500$ & 4 & 4 & $1,201-1,500$ & 9 & 9 \\
$1,501-1,800$ & 0 & 0 & $1,501-1,800$ & 13 & 13 \\
$1,801-2,100$ & 1 & 1 & $1,801-2,100$ & 0 & 0 \\
\hline Total & 97 & 100 & Total & 97 & 100 \\
\hline
\end{tabular}
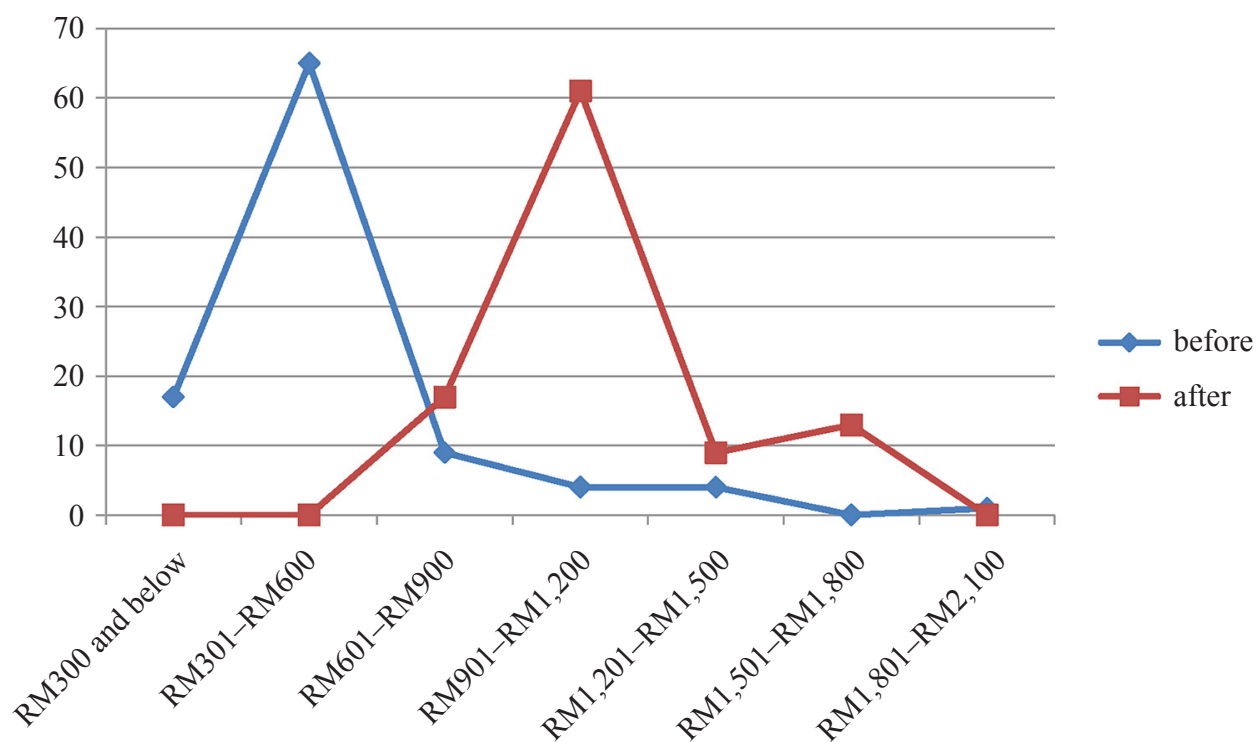

Figure 1: Income progress before and after joining the Agropolitan Project.

The Orang Asli respondents at Runchang (Pekan Agropolitan) have been earning a minimum income of RM640 monthly by working a minimum of five hours a day. In contrast, the respondents at Batu 8 Lepar (Pekan Agropolitan) earn up to RM60 per day. The participating residents within the Besut Setiu Agropolitan project have been paid about RM41 per day. Meanwhile, the South Kelantan Agropolitan participants earn about RM36 per day. The minimum wage per day depends on the output they can produce in a month and the job they do. If they cannot achieve an agreed monthly target, it is quite hard to get an increment. 
The participants also could earn supplementary income from secondary economic activities under the co-operative. For instance, in 2016 Koperasi Agropolitan Lepar Pekan Berhad (KALPB) has been recognised by the Malaysia Co-operative Societies Commission and received an award under the Agriculture and Agro-based Industry category. The recognition is due to their success in the poultry farming which currently employs six Agropolitan participants' family members. This co-operative had been consistently disbursing dividends to its members following its good performance and track record. They managed to secure contract farming with Ayamas Food Corporation Sdn Bhd since 2012. Moving forward, this co-operative also looking into selling Napier grass and silage to local breeders as there is growing demand in the agriculture industry.

Sean (2016) stated the chief executive officer of ECER Datuk Seri Jebasingam Issace John said the Agropolitan Project had provided a muchneeded platform for the lower-income individuals and families to transform their lives through agriculture-related economic activities. In addition to a stable job and steady income from the primary activity, the participants are also earning supplementary income from secondary economic activities under the co-operative. According to one of the participants in FGD:

In Besut Setiu Agropolitan, they pay us RM41 per day. The monthly salary is depend on the total number of days of work in a month. Starting from the first day we joint this programme in 2012 until now, the salary has not increased. It is not enough as the cost of living keeps increasing, and now I have a wife and children to take care of. (Respondent no. 2, Terengganu)

If the workers went to work for six days a week, their earnings peaked at RM1,066 per month. Nevertheless, one of the participants of FGD in South Kelantan Agropolitan stated:

I am so grateful they chose me to enter this project. If I had stayed with my previous job, earning up to RM800 monthly as a security guard, of which I had to pay RM300 for the house rental, RM150 for my motorcycle loan, utility bills and other expenses. On top of that, I needed to buy household groceries and pay the children's school fees. Now, I don't have to pay the rent just the utility bills. Furthermore, I can do some extra hours to cover my monthly expense, which is enough for a small family like ours. (Respondent no. 10, Kelantan)

As previously stated, the participants of this project do not need to pay for their house, and spouses can join "empower", a programme that teaches entrepreneurial skills and knowledge to aid their future. Their children are also provided with free 
tuition classes to improve their academic performance. This programme has also allowed the participants to invest their new disposable income on some luxuries, and it was noted during the research that this project has now provided a stable income so they can afford to take a loan to buy a used car.

Agropolitan Project is one of the initiatives taken by ECER to eradicate poverty in rural areas of Kelantan, Terengganu and Pahang. Since its commencement in 2009, this project has succeeded to transform a total of 1,180 participants from hardcore poverty within the region of ECER. Through this project, they have been given training in the palm oil plantation and Dorper sheep rearing. As a result, the income of the participants in Agropolitan Pekan, Agropolitan Besut-Setiu and Agropolitan South Kelantan have increased about RM1,900 monthly (ECERDC 2016). According to Department of Statistics Malaysia, the incidence of poverty in Kelantan and Terengganu also decreased from $7.2 \%$ and $6.5 \%$ in 2007 to $0.9 \%$ and $0.6 \%$ in 2014, respectively (United Nations Malaysia 2016). All the participants are currently listed out from the e-Kasih aid recipients.

Based on the observation, the income of respondents in South Kelantan Agropolitan do not meet at least an average monthly income of RM1,000 as what has been mentioned in ECER Annual Report for the year 2016. According to the report, the income of participants in the South Kelantan Agropolitan is between RM1,000 and RM1,900 for a month. It also happened for the participants in Runchang, which their average monthly income do not meet at least between RM900 and RM1,300 as stated in the report. The respondents also do not satisfy with the amount of income received as the cost of living today is getting higher.

\section{Socioeconomic Impacts and Overall Impacts}

Figure 2 shows the socioeconomic and overall impacts on the respondents of the Agropolitan Projects. Most of the respondents agreed that the Agropolitan Project has had at least a moderate impact on their lives including the economic, social and the environmental aspects. The maximum number of respondents $(61 \%)$ perceived that this project has a medium impact on the economics of the local community. Through this project, job opportunities are better and it has increased the income of local people. It also shows the empowerment of women (housewives) in improving the income of households by involving in the secondary activities and some of them are also participants in the survey. In general, the majority of the respondents $(53 \%)$ feel that this project has a medium impact in boosting their quality of life. The project has also brought them some positive improvements in their social well-being and lifestyle. 


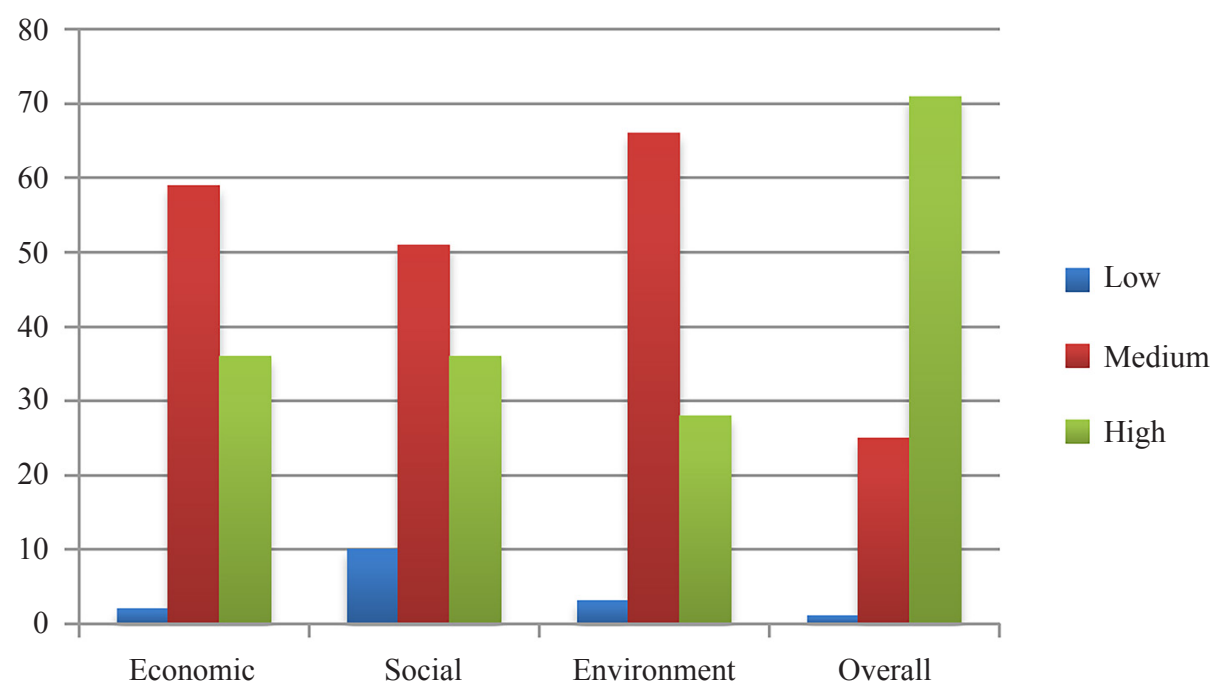

Figure 2: Socioeconomic and overall impacts of Agropolitan Project.

Most of them agreed that this project has improved the development of infrastructure and access to public facilities and amenities. Additionally, they also felt that the project has helped to reduce poverty, social issues and the crime problems among local communities. About $68 \%$ of the respondents believe the project does not affect the local environment or local climate including noise emissions. On the other hand, $73 \%$ of the participants were satisfied that this project had a high impact on their socioeconomic status as it improved their standard of living and brought about a positive change to their lives. According to one of the participants in FGD, he said:

Overall, I am satisfied with the project. As for suggesting, I hope that the management team can provide jobs for our wives to earn an extra income as our salary is not increasing while the cost of living keeps increasing. (Participant no. 6, Terengganu)

However, one of the informants from the implementation level said:

Overall, I would say that this project has had a very positive impact on the participants. At the early stage, we went through a detailed background check on the participants. We chose participants from families in abject poverty, and that was listed in e-Kasih. There were some candidates that I had interviewed who were unable to read and write, so, if we didn't help them who would? 
Once the chosen group came onto the programme, we organised religious activities to strengthen their spirituality, and they all bought into the idea of a cooperative. Some of them have since been elected as members of the village committees. In terms of remuneration, we aimed high but still not high enough for the participants at the moment. Our ultimate target is to achieve a monthly salary of RM5,000 for them. (Respondent no. 7, Kelantan)

As described to the participants during the induction session, these projects' aims are to increase their income by about RM500 annually. The programme has transformed the lives of participants as they are now not on the e-Kasih list. Since its commencement in 2009, the household income of Agropolitan participants has risen from below RM350 per month to an average of RM1,100 per month, and this figure is projected to grow to RM5,000 per month by 2020 (ECERDC 2012).

In future, the implementation of this eradication poverty programme will give attention to increase the income of participant's household and the sustainability of the project. Among the planned activities is agriculture-based seconder economic activity that can support the primary economic activity in the Agropolitan site project. Besides, a total of 250 students from participant's family will involve in empower academic programme to boost their academic performance. Apart from that, 210 of entrepreneurs will involve in course and training under the entrepreneur ECER organised by ECER Human Capital Development Division. Not only training, but the participants also will be given assistance to boost their sale and income (ECERDC 2016).

Nevertheless, despite its achievement, this project still can be described as a challenging project. There are still a few barriers to this project that are hindering the achievement of its ultimate goals.

The finding of this study shows:

1. Lack of increment to participant's income: The participants have been told that their income will increase from time to time. However, most of the participants are still paid at the same rate as the first day they joined this programme. They are now earning a stable income but it is not realistic to have no increment at all over a five-year period. In addition, there are no future saving nor any employment protection for them as they have not been registered with an Employees' Provident Fund (EPF) or an employment injury scheme. During the research, it was apparent that the project was also having some issues with the implementing agencies to manage this project properly. 
2. Sustainability of the project: This project has been implemented for over five years now and it still has not achieved their monthly target. It is about how long government should spend on this project and when is the right moment for the ECER to hand the project over. Up to date, the participants still do not have the required knowledge and skills to manage this project properly. This programme still cannot afford to empower them. It just teaches them how to become a good worker.

3. The attitude of the participants: It cannot be denied that the attitudes of the participants affect the sustainability of this project. They are used to getting government assistance and always ask for more. Most of them are still dependent on the government without using their own initiative to improve their life. Social problems like drug addiction are still prevalent among the participants. Their productivity does not achieve the required standard needed, as some are not capable of training to be a skilled worker.

4. Transparency in the selection of participants: There are some participants that should not be listed in this project. The project aim is to reach the families in real poverty, but there is a government worker and a few participants that earned more than RM1,500 per month joined this project. They were happy to be selected as it provides them with a free fully furnished house and complete public facilities in the residential area.

\section{CONCLUSION}

This article has highlighted the changes towards participant's occupation and income after joining this special project. Other than that, it has discovered socioeconomic impacts of the Agropolitan Project on the local people in the rural areas of Kelantan, Terengganu and Pahang which on balance are largely positive. It has transformed the participant's lives after joining the project especially in reducing the poverty issue, improving social well-being and lifestyle. It has provided job opportunities and increased income among the participants.

In contrast, there are also several issues related to participants that the implementing agencies need to overcome to achieve the projects ultimate goals. Based on the discussion, there is still room for improvement to make this project the best rural transformation project to eradicate poverty in Malaysia. ECER and the project operator should find an initiative to increase the productivity level of this project because it significantly increases the participant's income. An impactful secondary activity will contribute to the additional household incomes of the participants such as involvement of the participant's households 
in entrepreneurship activities. The government could use the information from this study as input for the evaluation and monitoring assessment of development programme because this project fully funded by public money. With regard to the impacts on local people, more research should be conducted on the future and the readiness of the local community to survive on their own without depending on government assistance. A holistic transformation could be a true success story of this human capital development project by ECER.

\section{REFERENCES}

Blomquist, J. 2003. Impact evaluation of social programs: A policy perspective. http:// siteresources.worldbank.org/SAFETYNETSANDTRANSFERS/Resources/ Evaluation_Blomquist.pdf (accessed 18 January 2018).

Christiaensen, L., L. Demery and J. Kuhl. 2011. The (evolving) role of agriculture in poverty reduction: An empirical perspective. Journal of Development Economics 96(2): 239-254. https://doi.org/10.1016/j.jdeveco.2010.10.006

Darko, F., A. Palacios-Lopez, T. Kilic and J. Ricker-Gilbert. 2018. Micro-level welfare impacts of agricultural productivity: Evidence from rural Malawi. The Journal of Development Studies 54(5): 915-932. https://doi.org/10.1080/00220388.2018 .1430771

Department of Statistics Malaysia. 2008. Incidence of poverty by states 2007, Malaysia. Kuala Lumpur: Department of Statistics Malaysia.

East Coast Economic Region Development Council (ECERDC). 2009. East coast economic region development council annual report 2008. Kuala Lumpur: ECERDC. .2010. East coast economic region development council annual report 2009. Kuala Lumpur: ECERDC.

.2012. East coast economic region development council annual report 2011. Kuala Lumpur: ECERDC.

.2013. East coast economic region development council annual report 2012. Kuala Lumpur: ECERDC.

2014. East coast economic region development council annual report 2013. Kuala Lumpur: ECERDC.

2016. East coast economic region development council annual report 2015. Kuala Lumpur: ECERDC.

.2017. East coast economic region development council annual report 2016. Kuala Lumpur: ECERDC.

Economic Planning Unit, Prime Minister's Department. 2006. Ninth Malaysia plan 20062010. Putrajaya: Economic Planning Unit, Prime Minister's Department.

Hazell, P. and Haddad. 2001. Agriculture research and poverty reduction: Food, agriculture and the environment. Discussion paper no.34. Washington, D.C.: International Food Policy Research Institute. 
Ibrahim Ngah. 2011. Challenges of regional development in Malaysia in the globalization context. https://www.researchgate.net/publication/283078879_Challenges_of_ Regional_Development_in_Malaysia_in_the_Globalization_Context (accessed 10 July 2018).

Irz, X., L. Lin, C. Thirtle and S. Wiggins. 2001. Agricultural productivity growth and poverty alleviation. Development Policy Review 19(4): 449-466. https://doi.org/ 10.1111/1467-7679.00144

Ivanic, M. and W. Martin. 2018. Sectoral productivity growth and poverty reduction: National and global impacts. World Development 109: 429-439. https://doi.org/ 10.1016/j.worlddev.2017.07.004

Khalid Ramli. 2007. Evaluation establishing outcome monitoring and evaluation in strategic context. Putrajaya: Implementation Coordination Unit of the Prime Minister's Department.

King, J. 2015. An update on the latest evaluation theories and models. http://www .cehd.umn.edu/OLPD/MESI/spring/2015/King-EvalTheoryUpdate.pdf (accessed 9 March 2016).

Leete, R. 2007. Malaysia from kampung to twin tower, 50 years of economics and social development. Kuala Lumpur: Oxford Fajar Sdn. Bhd.

Mabaso, S. 2014. Impact of agricultural development projects on poverty alleviation in Amajuba district municipality (KZN). http://vital.seals.ac.za:8080/vital/access/ manager/Repository/vital:11217

Mariana Mohamed Osman, Syahriah Bachok and Noor Suzilawati Rabe. 2015. Local residents' perception on socio-economic impact of Iskandar Malaysia: An example of urban regeneration program in Malaysia. Procedia - Social and Behavioral Sciences 170: 58-69. https://doi.org/10.1016/j.sbspro.2015.01.015

Mellor, J.W. 2001. Employment multipliers from agricultural growth and poverty reduction. Pakistan Development Review 40(4; Part 1): 371-400.

Mohamed Aslam Gulam Hassan and Asan Ali Golam Hassan. 2003. Development planning and regional imbalances in Malaysia. http://citeseerx.ist.psu.edu/viewdoc/ download?doi=10.1.1.194.6239\&rep=rep1\&type=pdf (accessed 25 July 2018).

Nik Maheran Nik Muhammad, Filzah Md Isa, Siti Norezam Othman and Haslina Che Yaacob. 2011. Regional economic development: Rethinking the region. Journal of Information Technology and Economic Development 2(1): 74-82.

Noor Suzilawati Rabe, Mariana Mohammed Osman and Syahriah Bachok. 2013. The conceptual framework of regional development in Malaysia. http://www .academia.edu/17048107/THE_CONCEPTUAL_FRAMEWORK_OF_ REGIONAL_DEVELOPMENT_IN_MALAYSIA (accessed 24 May 2018).

Osman Mohd Yusoff, Radin Firdaus Radin Baharudin, Mohamad Shaharudin Samsurijan and Suziana Mat Yasin. 2016. Development planning and administration in Malaysia: The Importance and challenges of evaluation. The Social Sciences 11: 5100-5103.

Rosegrant, M. and P. Hazell. 2001. Transforming the rural Asian economy: The unfinished revolution. Choice Reviews Online 39(1): 1-2. https://doi.org/10.5860/CHOICE $.39-0432$ 
Sean, O.H. 2016. KALB awarded for empowering the lower-income group. The Star Online. https://www.thestar.com.my/metro/community/2016/08/05/recognitionfor-cooperative-kalb-awarded-for-empowering-the-lowerincome-group

Thirtle, C., L. Lin and J. Piesse. 2003. The impact of research-led agricultural productivity growth on poverty reduction in Africa, Asia and Latin America. World Development 31(12): 1959-1975. https://doi.org/10.1016/j.worlddev.2003.07.001

United Nations Malaysia. 2016. Malaysia millennium development goals report 2015. Kuala Lumpur: United Nations Malaysia.

World Bank. 2000. Beyond economic growth: Meeting the challenges of global development. Washington, D.C.: The World Bank.

Yusof Ahmad, Hamid Saad, Yendo@Yendo Afgani and Naeemah Yusof. 2014. Quality of life amongst agropolitan participant project: A Malaysian experience. Procedia - Social and Behavioral Sciences 153: 479-490. https://doi.org/ 10.1016/j.sbspro.2014.10.081 